\title{
Parties Getting Impatient: Time Out of Office and Portfolio Allocation in Coalition Governments
}

\author{
ALBERT FALCÓ-GIMENO*
}

This article argues that long periods out of office make parties impatient and more willing to make concessions over portfolio allocation in exchange for participation in a coalition cabinet. Two hypotheses are analysed: on the one hand, being in opposition for a long time should put parties at a disadvantage when bargaining over office payoffs. On the other, this effect should not apply to the formateur party, since formation offers are based on the receivers' impatience. The empirical results largely support these expectations. Additional evidence of the causality of the main effect is obtained through the use of matching techniques based on the propensity score.

Impatience is by and large regarded as a handicap for those involved in almost any kind of negotiation. Generally speaking, the more patient players are, the more they can gain in a bargaining process. The urgency of an impatient actor can make him more willing to take benefits in the present, perhaps at the cost of a bigger prize at some time in the future. In political science, one of the most significant negotiation processes takes place in the formation of a new government. Specifically, when a coalition is established, the parties involved need to agree on a number of major issues, including the allocation of portfolios. The distribution of ministerial posts provides the most visible result of what each party has obtained in the bargaining process. Although it is true that the power that each partner will have in cabinet may be measured not only with respect to the ministries it will control, portfolio allocation represents the bottom line of this political process and often determines how influential parties will be in policy making. ${ }^{1}$ Therefore, the question arises of whether parties' impatience should play any role in this bargaining process.

Academics have for decades researched the reasons why some parties obtain more portfolios than others. In particular, scholarly interest in identifying the variables that affect the distribution of ministerial posts in coalition governments dates back to two seminal articles by William A. Gamson. ${ }^{2}$ Since that time, political scientists have aimed at answering the 'who-gets-what-and-why' question both theoretically and empirically. As James Druckman and Paul Warwick highlighted, researchers have assessed all the apparently significant variables that may potentially impact the allocation of

* Department of Political and Social Sciences, Universitat Pompeu Fabra, Barcelona, and Center for Advanced Study in the Social Sciences, Juan March Institute, Madrid (email: afalco@march.es). The author thanks Javier Arregui, Ignacio Urquizu, José R. Montero, and the Journal's anonymous reviewers for helpful comments on previous versions of this article, as well as the Juan March Institute for language assistance.

1 Michael Laver and Norman Schofield, Multiparty Government: The Politics of Coalition in Europe (Oxford: Oxford University Press, 1990).

2 William A. Gamson, 'A Theory of Coalition Formation', American Sociological Review, 26 (1961), 373-82; and William A. Gamson, 'An Experimental Test of a Theory of Coalition Formation', American Sociological Review, 26 (1961), 565-73. 
government posts. ${ }^{3}$ As a result, what has emerged is the prevalence of Gamson's law, namely, that parties involved in forming a coalition government tend to receive a share of portfolios proportional to the amount of resources (seat share) that each contributes to the coalition. The attributed status of 'law' reveals its apparently strong predictive power.

Unfortunately, however, '[t]he perceived robustness of Gamson's Law appears to have discouraged efforts to consider what other factors might influence portfolio allocation'. ${ }^{4}$ It is true that there are some exceptions to this, most notably the variables 'formateur status' and 'parties' bargaining power' beyond their seat share. However, the length of time parties have been out of government and their corresponding impatience to attain office have never been considered, either theoretically or empirically, to be an important determinant in the negotiation over portfolios in coalitions.

According to Laver, the theoretical underpinnings of 'one of the highest non-trivial $R$-squared figures in political science' are at best weak..$^{5}$ The mismatch between the theoretical predictions drawn from most bargaining models and the real-world evidence has become clear, inviting further research on the issue. There remains a need to inquire about other factors that may influence negotiations over the distribution of executive posts and for which we can provide a firmer theoretical basis. For the first time, this study assesses the potential effect of having spent a long time in opposition on parties' willingness to trade portfolios for participation in government. Exploring this link will further improve our understanding of the reasons underlying 'who gets what' in negotiations over coalition formation.

\section{THE ARGUMENT: IMPATIENCE AND OFFICE PAYOFFS}

Bargaining models have dealt with the issue of impatience by introducing the idea of temporal discounting. That is, keeping all other variables constant, a given payoff is valued more today than it is tomorrow. One implication that is normally derived from these bargaining models is that patience enhances the bargaining power of a negotiating party. It is therefore viewed as good to be patient when one is trying to get the most out of a negotiation. This rationale may also be applied to the world of coalition formation. Impatience should have a negative impact on the office payoffs that each party will eventually receive in the formation of a coalition government. An impatient party, the rationale goes, will be willing to settle for a smaller piece of the pie.

However, despite the intuitive appeal of this idea, the theoretical study of bargaining over government formation has typically regarded this temporal discount factor to be common to all parties. In other words, scholars have not allowed variation between parties through the idea of an idiosyncratic discount factor. ${ }^{6}$

In formal models of coalition formation, the utility $u_{i}$ that a party derives from the office payoffs $v_{i}$ that it obtains is generally weighted by a common discount factor $\delta \in(0,1)$.

\footnotetext{
3 James N. Druckman and Paul V. Warwick, 'The Missing Piece: Measuring Portfolio Salience in Western European Parliamentary Democracies', European Journal of Political Research, 44 (2005), 17-42.

4 Indridi H. Indridason, 'Live for Today, Hope for Tomorrow? Rethinking Gamson's Law', ECPR Joint Sessions of Workshops, Lisbon, 2009, p. 18.

5 Michael Laver, 'Models of Government Formation', Annual Review of Political Science, 1 (1998), 1-25, p. 7.

${ }^{6}$ See Antonio Merlo and Charles Wilson, 'A Stochastic Model of Sequential Bargaining with Complete Information', Econometrica, 63 (1995), 371-99, for an exception in a more general, formal model of legislative bargaining.
} 
This means that the total $u_{i}$ party $i$ gets from a formation agreement at round $t$ equals $\delta^{t-1} v_{i}$. That is, the later an agreement is reached, the less the utility that parties derive from the same portfolio share. Hence, everything else constant, parties tend to dislike delays. However, there is no reason to believe that this aversion will not vary across parties. If one allows them to vary in terms of impatience and considers a party-specific element in the discount factor, then a given party $i$ may discount future payoffs more or less than party $j$. If impatience is not distributed equally among all parties, the consequence would be that the more impatient a party is, the fewer portfolios it will be offered in the process of coalition cabinet formation.

\section{The Formateur Advantage}

If one reasons along the lines of a bargaining model of alternating offers (following the tradition started by Rubinstein's and Baron and Ferejohn's seminal contributions), ${ }^{7}$ the proposer starts from an advantageous position. This advantage mainly derives from the fact that the formateur - the party having the task of forming the government - basis her offers to her potential partners on their utilities - more specifically, their continuation values - and keeps the rest for herself. ${ }^{8}$ If, for instance, the formateur $i$ offers party $j$ a payoff $\delta_{j}{ }^{t-1} v_{j}$ equal to the continuation value of this party, the offer will be accepted and the formateur will obtain $1-\delta_{j}{ }^{t-1} v_{j}$ as a payoff. In these models it is always the case that 1 minus the offer is bigger than the offer itself.

So, if we are to believe the predictions of these types of models, then the effect that impatience may have in these negotiations should be no exception to the proposer advantage. The formateur will prepare her offers in the light of what the possible receivers would accept. Certainly, if one of these potential partners is desperate to get into office, then the offer making him indifferent between accepting and rejecting would be lower than if he had been more patient. So basically what impatience does is to decrease the price of potential partners.

Let us now consider the formateur's impatience. In the context of an 'alternating offers' model, the proposer will not 'introduce' her own impatience in the offers she makes (recall that she would simply receive 1 minus the share offered). It could be argued that the receiver, aware of the formateur's impatience, will reject the offer and wait for the opportunity to propose the distribution of spoils himself. However, these models predict that the first proposer will anticipate all subsequent moves and propose a distribution that will be accepted in the first round. It is worth mentioning that, given (i) a typical protocol of formateur selection if bargaining rounds happen to fail and (ii) a finite number of rounds, non-proposer parties do not have an incentive to reject the first offer and wait for one that takes the proposer's impatience into account, as that would be a non-credible

7 Seminal articles by Ariel Rubinstein, 'Perfect Equilibrium in a Bargaining Model', Econometrica, 50 (1982), 97-109; and David P. Baron and John A. Ferejohn, 'Bargaining in Legislatures', American Journal of Political Science, 89 (1989), 1181-206. Models of alternating offers are to be found in Joseph Harrington, 'The Power of the Proposal Maker in a Model of Endogenous Agenda Formation', Public Choice, 64 (1990), 1-20; David Austen-Smith and Jeffrey Banks, 'Stable Governments and the Allocation of Portfolios', American Political Science Review, 84 (1990), 891-906; Anastassios Kalandrakis, 'A ThreePlayer Dynamic Majoritarian Bargaining Game', Journal of Economic Theory, 116 (2004), 294-322; Tasos Kalandrakis, 'Proposal Rights and Political Power', American Journal of Political Science, 50 (2006), 441-8; Indridason, 'Live for Today, Hope for Tomorrow?'

${ }^{8}$ Hereafter, I will use female gender for the proposer and male for the receivers. 
threat. Hence, the proposed distribution will incorporate the receivers' impatience and not the formateur's in such a way that the latter, ceteris paribus, will select the cheapest partner with which to form a coalition. That will be the most impatient one, since the proposer will need to offer less office payoffs to gain the receiver's acceptance. ${ }^{9}$

Beyond this specific underlying model, the interaction between impatience and party status in negotiations is in any case worth testing against the data. We will explore below the extent to which being a formateur offsets the effect of impatience on how well the party does when bargaining over cabinet portfolios.

Admittedly, the approach taken in this work assumes that parties predominantly seek office. This study explores the specific scenario of negotiation over office payoffs, and remains silent about policy compromises. However, this does not mean that parties are treated as being policy-indifferent. In fact, as suggested later, there are reasons to substantively link parties' impatience with their policy-orientation. It is true, however, that the theoretical hypotheses and empirical tests will only address the specific outcome of the distribution of ministerial posts. Political parties in this work are thus assumed to derive utility from office payoffs 'holding policy constant', in a similar way to most other theoretical models that seek to predict portfolio allocations. As Budge and Laver put it, the assumption that those involved in coalition bargaining are motivated by the desire to get into government can be defended in two ways. Politicians may value the rewards of office per se, but also instrumentally, for the potential they confer of being able to influence public policy. In fact, the instrumental motive can be extended to electoral reasons as well: incumbency may give an advantage in future elections, and party leaders may seek office for this reason too. ${ }^{10}$

\section{IMPATIENCE AND TIME OUT OF OFFICE}

In practice, however, what accounts for parties' impatience? If parties are oriented towards seeking office (and this is one of the most prevalent assumptions in political science), then there is every reason to believe that time passing without the 'sweet taste' of office will make them more impatient. Along similar but more general lines, Renshon conceptualized political impatience as the perception that a politician may have that the amount of time waiting for a political reward has gone beyond the limits of what was personally expected and/or desired. ${ }^{11}$ Accordingly, this work explores the consequences of long periods in opposition when it comes to the time to negotiate an agreement on the formation of a multiparty government.

The core of the intuition is that the longer that parties are out of office, the more impatient they become, and the more willing they are to settle upon an agreement for a smaller share of the pie. Substantively, that is sustained in the notion that parties at some point feel the urge to be in the driver's seat. Why should this be the case? There may be various reasons. Parties that have not been in office for a long time, for example, will possibly be eager to take control because policy may have deviated far from their ideal point while in

${ }^{9}$ In another work related to this one I offer formal proof that this is the case. See Albert FalcóGimeno, 'Portfolio Allocation and Time Out of Office in Coalition Governments', Juan March Institute, CEACS Estudio/Working Paper 2011/254 (2011), 1-36.

${ }^{10}$ Ian Budge and Michael J. Laver, 'Office Seeking and Policy Pursuit in Coalition Theory', Legislative Studies Quarterly, 11 (1986), 485-506.

${ }^{11}$ Stanley A. Renshon, 'Temporal Orientations and Political Life: The Psychology of Political Impatience', British Journal of Political Science, 7 (1977), 262-72, at p. 262. 
opposition. That of course would provide room for interesting extensions of the basic argument, in which not all parties may become equally desperate for deciding policy from cabinet seats, as it would depend on the partisanship of previous governments. That implication, however, is beyond the scope of this work.

Impatience and time out of office may be also linked due to intra-party politics. Being in office makes specific rewards available, such as politically discretionary appointments, control over government contracts, preferential treatment, etc. Given that party activists perform demanding organizational tasks and professional services, party leaders need to compensate them, at least partly, with private benefits. Because public office generates potential private benefits (such as those mentioned above), party leaders will need to govern at some point, if only for those below them. As Müller and Strom put it, '[b]ecause party resources typically depend so heavily on elective office, compensation tends to be prospective. Activists perform needed services in exchange for promises of future benefits to be delivered if and when the party wins office'. ${ }^{12}$

There can certainly be other motives behind parties' impatience. Nonetheless, the situational determinant of office deprivation is also very likely to add to their impatience. A few real-world instances will help back up this claim. These examples are drawn from a well-known book by Wolfgang C. Müller and Kaare Strom, which analyses cases of conflicting parties' goals in Western Europe.

Party leadership decisions are made in specific situations, and the nature of these situations may differ in important ways, even when institutions and organizations do not. The same party leaders may have different trade-off functions in different situations. ... Parties that have previously been electorally successful but starved of office benefits, such as the Italian PCI in the 1970s, may be willing to swallow unusual compromises in order to gain representation at the cabinet table, whereas parties used to executive office may be more willing to wager such benefits in the hope of securing electoral gains, as did Norwegian Labour Prime Minister Thorbjorn Jagland in $1997 .{ }^{13}$

Similarly,

One situational factor that may easily affect strategies of party leaders is their initial endowments of votes, office, and policy benefits. Broadly speaking, we would expect that the less a given party has enjoyed of a particular good, the more it is likely to value that type of payoff. In Sweden, for example, the nonsocialist parties, and particularly the Liberals and Conservatives, had been out of office for so long that it was desperately important to them to position themselves well for the upcoming elections. ... The new Conservative leader, Gosta Bohman, was especially eager to cement an alliance with the Liberals and the Center Party. The situation of office deprivation no doubt contributed to the policy compromises that the nonsocialist parties, and the Conservatives specifically, were willing to make. ${ }^{14}$

More explicitly related to office payoffs, Ron Hillebrand and Galen A. Irwin's reading of a bargaining round of the 1989 government formation in the Netherlands illustrates well the specific question that this article discusses: To what extent does office deprivation lead parties to trade ministerial posts for entrance into government?

This break in the coalition suddenly opened the door again for the Labour Party. Even those who believed that the Christian Democrats would accept the Socialists only as a last resort

\footnotetext{
12 Wolfgang C. Müller and Kaare Strom, eds, Policy, Office, or Votes? How Political Parties in Western Europe Make Hard Decisions (Cambridge: Cambridge University Press, 1999), pp. 15-16.

13 Müller and Strom, Policy, Office, or Votes, pp. 24-5.

14 Müller and Strom, Policy, Office, or Votes, p. 299.
} 
could see that this was an ideal opportunity. Some in the Labour Party went even further in their analysis and saw this as a do-or-die situation. The desire and pressure for office were greater than at any time in recent memory. If Labour could not obtain governmental responsibility now, it might never again do so. If, under these circumstances, the party, as the second largest party in the country, could not show that it was capable of being an acceptable coalition partner and a responsible governing party, it would lose all credibility with the voters. ... [Following the 1989 general election, the Labour Party] demanded that D66 be included in any negotiations regarding a centre-left coalition. The Christian Democrats countered with the proposal that this was agreeable, but that any ministerial posts allocated to D66 would have to come out of the Labour allocation. ... In the past, such a demand would have been rejected outright by Labour negotiators. In previous Cabinet [sic] formations they had placed their own demands on the number of posts they felt they should have. Now they were being asked to accept a less than proportional share. Out of their overwhelming desire to return to power and out of fear that a Christian Democratic-Liberal coalition, with or without D66, might yet be arranged, Labour submitted to the demand. ${ }^{15}$

\section{Hypotheses}

Beyond the theoretical relevance of the concepts of parties' impatience and time out of office, the above issues have previously been addressed empirically in the analyses of portfolio allocation in coalition governments. This is why this work seeks to test the following two hypotheses against the data:

HYPOTHESIS 1: In general, the more time a party has been out of office, the more likely it is to be under-compensated in terms of portfolio allocation in the formation of a coalition government.

HYPOTHESIS 2: If any, the consequences of time passed out of office when negotiating over portfolios in the formation of a coalition government will be much less severe for formateur parties.

\section{DATA AND VARIABLES}

The empirical test of the hypotheses above requires data on portfolio allocations in coalition governments at the party level. This information is needed because the main argument in this research is party-specific - as opposed to studies that treat the proportionality of portfolio allocation as a cabinet feature. Paul V. Warwick and James N. Druckman's dataset 'Portfolio's Data' provides the required structure and variables. The dataset covers the coalition governments of fourteen West European democracies from 1945 to $2000 .{ }^{16}$

\section{The Dependent Variable}

The dependent variable in this work is the share of ministerial posts that each party obtains from the negotiation over formation. So, the first specification of the dependent variable is simply the share of portfolios received by a given party (Portfolio Share).

\footnotetext{
15 Ron Hillebrand and Galen A. Irwin, 'Changing Strategies: The Dilemma of the Dutch Labour Party', in Müller and Strom, eds, Policy, Office, or Votes?, pp. 112-140, esp. pp. 124-6.

${ }^{16}$ The countries are Austria, Belgium, Denmark, Finland, France (Fifth Rep.), Iceland, Ireland, Italy, Luxembourg, Netherlands, Norway, Portugal, Sweden and (West) Germany.
} 
Given the prevalent proportional relationship between seat shares and portfolio shares (i.e. Gamson's law), I also employed another measure of parties' office payoffs. Since I am interested in analysing whether or not the length of time a party has been away from office becomes a liability when they are sitting at the negotiation table to discuss portfolios, I take the 'normal' allocation (i.e. proportionality) as a reference point and consider deviations from that distribution in order to measure ministerial under- and overcompensations. That is, to what extent the final representation obtained by each party diverges from the portfolios it 'should' have received according to what is 'fair and normal' under Gamson's law. The difference between portfolio share and seat share is what Warwick and Druckman call the Portfolio Differential. ${ }^{17}$ The resulting value can be either positive or negative, where the former indicates that the party has received an oversized portfolio share, and the latter reflects under-compensation, relative to party size. Note that the aim here is to predict party-specific deviations from proportionality rather than overall cabinet disproportionality.

Both dependent variables (Portfolio Share and Portfolio Differential) are in turn measured by: (i) considering the simple proportion of ministries obtained and (ii) adjusting them according to their importance. ${ }^{18}$ This is why the results presented in the next section are first divided into two tables: one for the non-weighted measures and the other for those that are weighted. This division will allow us to see whether the effect of the explanatory variables on the dependent variable is different depending on how we measure the latter.

\section{The Variable 'Time Out of Office'}

Given its widespread omission, it is perhaps not surprising to discover that Warwick and Druckman's database did not incorporate any variable measuring how long partners in coalition cabinets had been in opposition before entering government. For this reason, I decided to start a data collection process so as to measure that time. The main objective was to attribute a value to every party-government observation in order to measure the period that passed between the end of the last government in which the party participated and the formation of the new government that included it again. I measured that value both in terms of (i) years passed and (ii) the number of government formations that occurred. ${ }^{19}$ Given that the theoretical mechanism proposed here is based on parties' impatience, it made sense to add the latter and interpret formations as 'missed opportunities' that may augment parties' eagerness to enter office.

Unfortunately, the dataset 'Portfolio's Data' only includes data on coalition governments. Clearly, the appropriate measurement of the main independent variable requires us to take into account participation in any kind of government, and not only in multiparty ones.

17 This concept first appears in Paul V. Warwick and James N. Druckman. 'The Portfolio Allocation Paradox: An Investigation into the Nature of a Very Strong but Puzzling Relationship', European Journal of Political Research, 45 (2006), p. 657. Other authors had previously shown the usefulness of taking Gamson's mispredictions as a dependent variable (see Norman Schofield and Michael Laver, 'Bargaining Theory and Portfolio Payoffs in European Coalition Governments 1945-83', British Journal of Political Science, 15 (1985), 143-64).

${ }^{18}$ The weighted measure chosen is what Warwick and Druckman call 'Weighted Portfolio Share II' in Warwick and Druckman, 'The Portfolio Allocation Paradox'. See also Druckman and Warwick, 'The Missing Piece' for a thorough discussion of the measurement of portfolio salience.

19 In fact the calculations were based on months rather than years, although the final variables here are presented in years but without losing measurement detail (e.g.: 15 months $=1.25$ years). 
To adapt it, I merged the aforementioned database with that used by Warwick to study government survival. ${ }^{20}$ However, the latter provided no information after 1989, so I added the 'missing' single-party governments for the remaining years by drawing on Keesing's Record of World Events.

Next, two additional issues were addressed: (i) the starting point (i.e. the first government under consideration) and (ii) the challenge of how to deal with those parties created after that starting point. Regarding the former, the chosen baseline formation date was that of the first government for which data were available after $1944 .^{21}$

For newly created parties I could not take the first post-1944 government formation as a reference point to measure appropriately the time they had remained in opposition. Clearly, if a modern green party attained office in 1995, for example, it could not be said that it has been fifty years in waiting. For this reason I analysed each country's parliamentary composition after every election and ascribed a later reference point for every party without representation in the first parliament. Given the theoretical basis of this work, I ruled out the dates of foundation and of first receiving votes and opted instead for the first time these parties obtained parliamentary representation (i.e. at least one seat).

The resulting variables are thus Time Out of Office ( $Y$ ) (in years) and Time Out of Office $(F)$ (in government formations), each with two different specifications. Apart from the measurement explained above, I also calculated how long a party had been out of government in comparison to the other coalition partners. Since the main purpose of this study is to test to what extent the period a given party has been away from office makes a difference at the time of bargaining over the allocation of portfolios with coalition partners, this second empirical specification is also theoretically relevant. As a result, the statistical models below present the main independent variable, both in absolute and relative terms (time out of office relative to the mean of cabinet partners).

\section{Other Variables}

The remaining regressors are standard in the field. First, parties' Seat Share and parties' legislative Voting Weight (a typical index of power). These two variables that measure parties' endowments are included when the dependent variable is Portfolio Share. When it is Portfolio Differential instead, I follow Warwick and Druckman and collapse the two independent variables into a single one so as to measure parties' bargaining strength relative to their size. This is referred to as the Bargaining Differential: the difference between parties' voting weight and seat share. Again, this variable can take positive (over-endowment in terms of bargaining power relative to size) or negative values (under-endowment). ${ }^{22}$

Finally, I have also included the formateur status as an independent variable. Formateur is 1 for those parties who have the task of forming the government, and is 0 for the rest. Hypothesis 2 requires statistical models to include the interaction Time Out of Office $\times$ Formateur, so as to test whether or not the expectation that impatience will play a disadvantageous role only for non-formateur parties holds.

\footnotetext{
${ }^{20}$ Paul V. Warwick, Government Survival in Parliamentary Democracies (Cambridge: Cambridge University Press, 1994).

21 Recall that for those parties with non-democratic periods the starting year is a later one, and that for France the dataset only takes into account the Fifth Republic (that is, from 1959 onwards).

22 Warwick and Druckman, 'The Portfolio Allocation Paradox', p. 657.
} 
Given the nature of the dependent variable, ordinary least squares (OLS) linear regressions were employed as a statistical technique, and specified standard errors clustered by cabinet so as to address the compositional characteristic of the data. ${ }^{23}$ The results of the models without the interactions are displayed in Tables 1 and 2 .

Table 1 offers the estimates for the models with the unweighted dependent variablethat is, assuming that all portfolios are valued the same. A glance at the table reveals that the first hypothesis of this article seems to hold fairly strongly. Overall, it shows that the longer a party has been in opposition, the fewer portfolios it receives when it eventually enters a coalition government. Additionally, the specific Time Out of Office measurement seems to exert a slight influence on the results. The number of past government formations that were not conducive to the participation of the party in government appears to work somewhat better than if measured through pure units of time (i.e. years), in terms of statistical significance. However, this minor difference completely disappears when both measures are calculated in relative terms.

The corresponding models in Table 2 reveal the same, if not an even stronger, tendency. The longer the period a given party has been out of power, the more under-compensated it will be in terms of office payoffs (now weighted by importance). The signs are once more in the right direction and now they all reach conventional levels of statistical significance. On the whole, the effect of Time Out of Office holds robustly regardless of the particular measure of the independent (absolute and relative) and dependent variables (either weighted or not, and both for plain portfolio shares as well as for differentials).

Finally, most of the remaining variables behave as expected. Both parties' size and bargaining strength increase the portfolios obtained. So, parties receive office payoffs in proportion to their seat share (though not exactly on a 1:1 basis as Gamson's law would suggest) and are further helped by their bargaining power. In addition, the models with differentials suggest that a party that is over-endowed in terms of bargaining power (in relation to its size) manages to receive more portfolios than one would expect by simply looking at its seat share.

\section{The Formateur Effect}

Counter to expectations, the party entrusted with the task of forming the government is not necessarily over-compensated in terms of portfolio allocation. In fact, the outcome mostly depends on how the dependent variable is measured. In Table 1 we see that the coefficients associated with Formateur are systematically negative. Once we control for size and bargaining strength, being responsible for making government formation offers puts the party at a disadvantage in terms of the absolute number of ministerial posts it receives.

However, the picture looks notably different when the importance of the portfolio is taken into account. According to Warwick and Druckman, '[w]ith the application of salience weightings, ... lumpiness is smoothed out and a truer assessment of the nature of the underlying relationship becomes obtainable'. ${ }^{24}$ Lumpiness - the fact that portfolios

\footnotetext{
23 See Indridason, 'Live for Today, Hope for Tomorrow?' for a thorough discussion of the issue.

24 Warwick and Druckman, 'The Portfolio Allocation Paradox', p. 647. For more information on the lumpiness concept, see also Paul V. Warwick and James N. Druckman, 'Portfolio Salience and the Proportionality of Payoffs in Coalition Governments', British Journal of Political Science, 31 (2001), $627-49$.
} 
TA B L 1 Regression Analyses for Parties' Portfolio Allocations (Non-Weighted)

\begin{tabular}{|c|c|c|c|c|c|c|c|c|}
\hline & \multicolumn{4}{|c|}{ DV: Portfolio Share } & \multicolumn{4}{|c|}{ DV: Portfolio Differential } \\
\hline & \multicolumn{2}{|c|}{$\begin{array}{l}\text { Time Out of Office in } \\
\text { Absolute Terms }\end{array}$} & \multicolumn{2}{|c|}{$\begin{array}{l}\text { Time Out of Office in } \\
\text { Relative Terms }\end{array}$} & \multicolumn{2}{|c|}{$\begin{array}{c}\text { Time Out of Office in } \\
\text { Absolute Terms }\end{array}$} & \multicolumn{2}{|c|}{$\begin{array}{l}\text { Time Out of Office in } \\
\text { Relative Terms }\end{array}$} \\
\hline & (1) & (2) & (3) & (4) & $(5)$ & (6) & (7) & (8) \\
\hline $\begin{array}{l}\text { Seat Share } \\
\text { Voting Weight }\end{array}$ & $\begin{array}{l}0.7863^{* * *} \\
(0.023) \\
0.1048^{* * *} \\
(0.031)\end{array}$ & $\begin{array}{l}0.7853^{* * *} \\
(0.023) \\
0.1051 * * * \\
(0.031)\end{array}$ & $\begin{array}{l}0.7855^{* * *} \\
(0.023) \\
0.1068 * * * \\
(0.031)\end{array}$ & $\begin{array}{l}0.7851 * * * \\
(0.023) \\
0.1068 * * * \\
(0.031)\end{array}$ & & & & \\
\hline Bargaining Differential & & & & & $\begin{array}{l}0.1983^{* * *} \\
(0.027)\end{array}$ & $\begin{array}{l}0.1991^{* * *} \\
(0.027)\end{array}$ & $\begin{array}{l}0.1993^{* * *} \\
(0.027)\end{array}$ & $\begin{array}{l}0.1996^{* * * *} \\
(0.027)\end{array}$ \\
\hline $\begin{array}{l}\text { Formateur } \\
\text { Time Out of Office }(Y)\end{array}$ & $\begin{array}{l}-0.0349 * * * \\
(0.009) \\
-0.0006^{\dagger} \\
(0.000)\end{array}$ & $\begin{array}{l}-0.0349 * * * \\
(0.009)\end{array}$ & $\begin{array}{l}-0.0354 * * * \\
(0.009) \\
-0.0011 * * \\
(0.000)\end{array}$ & $\begin{array}{l}-0.0351 * * * \\
(0.009)\end{array}$ & $\begin{array}{l}-0.0584^{* * *} \\
(0.009) \\
-0.0005^{\dagger} \\
(0.000)\end{array}$ & $\begin{array}{l}-0.0586^{* * * *} \\
(0.009)\end{array}$ & $\begin{array}{l}-0.0588^{* * *} \\
(0.009) \\
-0.0012 * * \\
(0.000)\end{array}$ & $\begin{array}{l}-0.0585^{* * * *} \\
(0.009)\end{array}$ \\
\hline Time Out of Office $(F)$ & & $\begin{array}{l}-0.0013 * * * \\
(0.000)\end{array}$ & & $\begin{array}{l}-0.0013 * * * \\
(0.000)\end{array}$ & & $\begin{array}{l}-0.0011 * * * \\
(0.000)\end{array}$ & & $\begin{array}{l}-0.0014 * * * \\
(0.000)\end{array}$ \\
\hline Constant & $\begin{array}{l}0.0626^{* * * *} \\
(0.004)\end{array}$ & $\begin{array}{l}0.0633^{* * *} \\
(0.004)\end{array}$ & $\begin{array}{l}0.0615^{* * *} \\
(0.004)\end{array}$ & $\begin{array}{l}0.0615^{* * *} \\
(0.004)\end{array}$ & $\begin{array}{l}0.0460 * * * \\
(0.003)\end{array}$ & $\begin{array}{l}0.0466^{* * *} \\
(0.003)\end{array}$ & $\begin{array}{l}0.0454^{* * * *} \\
(0.003)\end{array}$ & $\begin{array}{l}0.0453^{* * * *} \\
(0.003)\end{array}$ \\
\hline Observations & 770 & 770 & 770 & 770 & 770 & 770 & 770 & 770 \\
\hline$R$-squared & 0.895 & 0.896 & 0.895 & 0.895 & 0.356 & 0.357 & 0.357 & 0.357 \\
\hline
\end{tabular}

Note: Standard errors clustered by cabinet are shown in parentheses. ${ }^{* * *} p<0.01,{ }^{* *} p<0.05,{ }^{*} p<0.10$. ${ }^{\dagger}$ Indicates confidence intervals from 0.8 to 0.9 . 
TA B Le 2 Regression Analyses for Parties' Portfolio Allocations (Weighted)

\begin{tabular}{|c|c|c|c|c|c|c|c|c|}
\hline & \multicolumn{4}{|c|}{ DV: Portfolio Share } & \multicolumn{4}{|c|}{ DV: Portfolio Differential } \\
\hline & \multicolumn{2}{|c|}{$\begin{array}{l}\text { Time Out of Office in } \\
\text { Absolute Terms }\end{array}$} & \multicolumn{2}{|c|}{$\begin{array}{l}\text { Time Out of Office in } \\
\text { Relative Terms }\end{array}$} & \multicolumn{2}{|c|}{$\begin{array}{l}\text { Time Out of Office in } \\
\text { Absolute Terms }\end{array}$} & \multicolumn{2}{|c|}{$\begin{array}{l}\text { Time Out of Office in } \\
\text { Relative Terms }\end{array}$} \\
\hline & (1) & (2) & (3) & (4) & $(5)$ & (6) & (7) & (8) \\
\hline Seat Share & $\begin{array}{l}0.7663 * * * \\
(0.021)\end{array}$ & $\begin{array}{l}0.7652 * * * \\
(0.021)\end{array}$ & $\begin{array}{l}0.7653 * * * \\
(0.021)\end{array}$ & $\begin{array}{l}0.7649 * * * \\
(0.021)\end{array}$ & & & & \\
\hline Voting Weight & $\begin{array}{l}0.0976^{* * * *} \\
(0.028)\end{array}$ & $\begin{array}{l}0.0979 * * * \\
(0.028)\end{array}$ & $\begin{array}{l}0.1001 * * * \\
(0.028)\end{array}$ & $\begin{array}{l}0.1001 * * * \\
(0.028)\end{array}$ & & & & \\
\hline Bargaining Differential & & & & & $\begin{array}{l}0.2144 * * * \\
(0.027)\end{array}$ & $\begin{array}{l}0.2153^{* * *} \\
(0.027)\end{array}$ & $\begin{array}{l}0.2157 * * * \\
(0.027)\end{array}$ & $\begin{array}{l}0.2161^{* * * *} \\
(0.027)\end{array}$ \\
\hline Formateur & $\begin{array}{l}0.0179^{* *} \\
(0.009)\end{array}$ & $\begin{array}{l}0.0179 * * \\
(0.009)\end{array}$ & $\begin{array}{l}0.0172 * \\
(0.009)\end{array}$ & $\begin{array}{l}0.0177 * * \\
(0.009)\end{array}$ & $\begin{array}{r}-0.0115 \\
(0.009)\end{array}$ & $\begin{array}{r}-0.0117 \\
(0.009)\end{array}$ & $\begin{array}{c}-0.0120 \\
(0.009)\end{array}$ & $\begin{array}{r}-0.0117 \\
(0.009)\end{array}$ \\
\hline Time Out of Office (Y) & $\begin{array}{l}-0.0008^{*} \\
(0.000)\end{array}$ & & $\begin{array}{l}-0.0014^{* *} \\
(0.001)\end{array}$ & & $\begin{array}{l}-0.0007 * \\
(0.000)\end{array}$ & & $\begin{array}{l}-0.0015^{* * * *} \\
(0.001)\end{array}$ & \\
\hline Time Out of Office ( $F)$ & & $\begin{array}{l}-0.0014 * * * \\
(0.000)\end{array}$ & & $\begin{array}{l}-0.0017 * * * \\
(0.000)\end{array}$ & & $\begin{array}{l}-0.0012 * * * \\
(0.000)\end{array}$ & & $\begin{array}{l}-0.0017^{* * * *} \\
(0.000)\end{array}$ \\
\hline Constant & $\begin{array}{l}0.0539^{* * *} \\
(0.004)\end{array}$ & $\begin{array}{l}0.0546^{* * *} \\
(0.004)\end{array}$ & $\begin{array}{l}0.0526^{* * *} \\
(0.004)\end{array}$ & $\begin{array}{l}0.0526^{* * *} \\
(0.004)\end{array}$ & $\begin{array}{l}0.0332 * * * \\
(0.003)\end{array}$ & $\begin{array}{l}0.0337^{* * *} \\
(0.003)\end{array}$ & $\begin{array}{l}0.0324 * * * \\
(0.003)\end{array}$ & $\begin{array}{l}0.0323^{* * *} \\
(0.003)\end{array}$ \\
\hline Observations & 770 & 770 & 770 & 770 & 770 & 770 & 770 & 770 \\
\hline$R$-squared & 0.915 & 0.915 & 0.915 & 0.915 & 0.232 & 0.234 & 0.235 & 0.235 \\
\hline
\end{tabular}

Note: Standard errors clustered by cabinet in parentheses. ${ }^{* * *} p<0.01, * * p<0.05, * p<0.10$. 
TA B LE 3 Regression Analyses for Parties' Portfolio Allocations (Interactions)

DV: Portfolio Differential

(Non-weighted)

(1)

\begin{tabular}{|c|c|c|c|c|}
\hline Bargaining Differential & $\begin{array}{l}0.1996^{* * * *} \\
(0.027)\end{array}$ & $\begin{array}{l}0.2006^{* * *} \\
(0.027)\end{array}$ & $\begin{array}{l}0.2171^{* * *} \\
(0.027)\end{array}$ & $\begin{array}{l}0.2176^{* * *} \\
(0.027)\end{array}$ \\
\hline Formateur & $\begin{array}{l}-0.0595 * * * \\
(0.010)\end{array}$ & $\begin{array}{l}-0.0608 * * * \\
(0.010)\end{array}$ & $\begin{array}{c}-0.0137 \\
(0.010)\end{array}$ & $\begin{array}{r}-0.0151 \\
(0.010)\end{array}$ \\
\hline Time Out of Office (Y) (Absolute) & $\begin{array}{c}-0.0007^{\dagger} \\
(0.000)\end{array}$ & & $\begin{array}{l}-0.0010^{* *} \\
(0.000)\end{array}$ & \\
\hline Time Out of Office (F) (Absolute) & & $\begin{array}{l}-0.0014 * * * \\
(0.000)\end{array}$ & & $\begin{array}{l}-0.0017 * * * \\
(0.000)\end{array}$ \\
\hline TOO (Y) (Abs.) x Formateur & $\begin{array}{c}0.0011 \\
(0.001)\end{array}$ & & $\begin{array}{l}0.0022^{\dagger} \\
(0.002)\end{array}$ & \\
\hline TOO (F) (Abs.) x Formateur & & $\begin{array}{l}0.0035^{*} \\
(0.002)\end{array}$ & & $\begin{array}{l}0.0053^{* * *} \\
(0.002)\end{array}$ \\
\hline Constant & $\begin{array}{l}0.0465^{* * *} \\
(0.003)\end{array}$ & $\begin{array}{l}0.0472 * * * \\
(0.003)\end{array}$ & $\begin{array}{l}0.0346^{* * *} \\
(0.003)\end{array}$ & $\begin{array}{l}0.0346^{* * * *} \\
(0.003)\end{array}$ \\
\hline Observations & 770 & 770 & 770 & 770 \\
\hline$R$-squared & 0.356 & 0.358 & 0.234 & 0.239 \\
\hline
\end{tabular}

Notes: Standard errors clustered by cabinet in parentheses. ${ }^{* * *} p<0.01,{ }^{* *} p<0.05,{ }^{*} p<0.10$.

${ }^{\dagger}$ Indicates confidence intervals from 0.8 to 0.9 .

are always allocated in their entirety to single parties - may produce a bias in favour of small parties and in turn explain why leading the government formation process does not provide any boost to the office payoffs obtained. This is to some extent supported in Table 2, which offers the results with the weighted dependent variable. Contrary to Table 1's preliminary conclusions, formateur status makes parties more likely to obtain a larger share of office payoffs (positive coefficients in Models 1 to 4). This is not the case, however, when considering differentials. Formateur parties appear not to be overcompensated in relation to their size.

However, as suggested in the theoretical section of this article, the formateur advantage may also emerge in a different way. If formateur parties make their offers on the basis of their potential partners' continuation values, the formers' impatience should not matter for portfolio allocation and only becomes a liability for non-formateur parties. We have seen that on average the longer the time a party has stayed in opposition, the more likely it is to be under-compensated later in terms of portfolios. But does the formateur status make any difference as suggested in Hypothesis 2?

Table 3 provides the estimates for the interactive effects. ${ }^{25}$ First, two out of the four interactions reach statistical significance. The other two have the expected positive sign, with one of them being very close to a 90 per cent level of confidence. Some slight differences related to the measurement of the main independent variable emerge again and, once more, the positive formateur effect is stronger for the weighted dependent variable.

\footnotetext{
${ }^{25}$ For the sake of presentational simplicity, in these tables Time Out of Office is measured simply in absolute terms. Results with the relative measure are highly similar.
} 


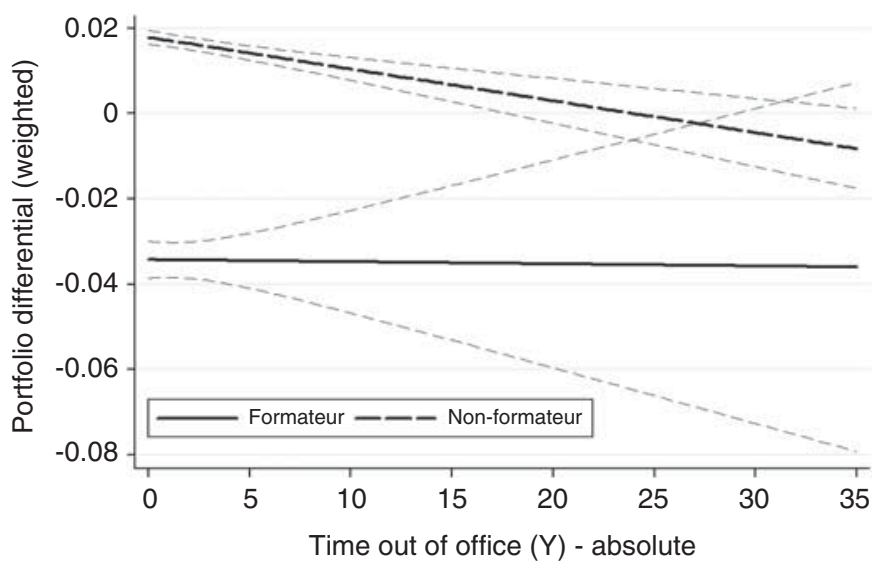

Fig. 1. Bivariate linear prediction plot: Time Out of Office ( $Y$ ) in absolute terms on Portfolio Differential (Weighted)

Figure 1 provides a graphical representation that may contribute to an even better understanding of this interactive relationship. It presents a linear prediction plot with confidence intervals ( 90 per cent) showing the two-way relationship between Time Out of Office and office payoffs. In line with the evidence presented so far, Figure 1 suggests that a long time in opposition translates into a significant bargaining handicap for nonformateur parties, whereas this does not seem to be the case for formateurs.

\section{ON THE CAUSALITY OF THE MAIN EFFECT: AN EXPLORATION USING MATCHING TECHNIQUES}

To this point, this work has demonstrated that when traditional variables are controlled for, the political parties that spend a longer time out of office tend to be undercompensated in terms of portfolio payoffs when they eventually join a coalition government, and especially so for non-formateur parties. But to what extent is this relation really causal? In the first part of the article it has been theorized that the causal micro-mechanism works through impatience. Everything else being equal, parties want to reach office, and the longer they have not been able to do so, the more their impatience increases. Then, they start discounting the future more intensely and that will come up in the negotiation over the formation of a coalition cabinet. Roughly put, the longer they have been in opposition, the more desperate they become to reach office, and the more willing they are to trade portfolios for 'mere' participation in government. But this causal argument only holds under a particular theoretical assumption: namely, that the reason they have remained out of office is not because they have been unwilling to participate but unable. This view assumes that, if parties have the opportunity, they will always seek office, and that they do not refuse entrance into government for some other strategic reasons beyond office payoffs. ${ }^{26}$

${ }^{26}$ Arguments in this vein are outlined, for instance, in Müller and Strom, Policy, Office, or Votes. For an application to the Spanish case, see Josep M. Reniu and Torbjörn Bergman, 'Estrategias, Objetivos y Toma de Decisiones de los Partidos Políticos Españoles en la Formación de Gobiernos Estatales', Politica y Sociedad, 40 (2003), 63-76. 
For instance, one could think that those that remain for longer periods in opposition are more policy-seeking than office-seeking, and this is precisely the reason why they get fewer portfolios than they 'should' when for whatever reason they finally participate in a multiparty cabinet. It might be simply that they value office less highly. However, from a game-theory perspective, if a given party values each piece of office less, the implication would be that it should be offered more to meet their indifference threshold. As a result, this argument would yield expectations contrary to those posed in this article, and against the real-world evidence we have seen.

Other interpretations of the observed relation would include extremist parties or "noncoalitionable' parties. As long as most parties in a given country judge another party as an undesirable partner, the latter will be more likely to be deprived of office. One of the possible ways to face their potential partners' reluctance and enhance its attractiveness would be to decrease its own price and thus accept a smaller payoff than a potential partner who has (or could have) been regularly in office. Anyhow, this argument could still be understood in terms of impatience, though now the reason behind it would not simply be the inability to reach office, but the other parties' preferences.

In any case, these questions need to be addressed carefully and a further assessment of the issue of causality seems advisable. Although it is true that the empirical evidence provided so far does not operate in a theoretical vacuum (an informal argument on parties' idiosyncratic discount factors as well as real-world qualitative illustrations have been offered), the extent to which the effect of the variable Time Out of Office on the portfolio payoffs obtained is truly causal needs to be assessed empirically as well.

Given the problem at hand, one way forward would be to examine parties with similar ex ante propensities to spend longer periods out of office, and compare the effect of actual stays in opposition with their chances of obtaining portfolios in coalition governments. This is similar to the intuition behind matching techniques that estimate the average effect of a treatment on those treated. In our case, the treatment would be the time a given party has been out of office. Then the question is to what extent a party that has been 'treated' with some time out of office is disadvantaged in the negotiation of office payoffs in a coalition government formation when compared to a similar party that has not been treated (e.g. was present in the previous government).

\section{Estimating the Average Treatment Effect for the Treated}

As suggested above, there are reasons to believe that the distribution of treatment is not random across parties and that there is some selection going on. There are indeed variables that affect the likelihood of participation in treatment. One has to identify these pre-treatment variables so that the assignment to treatment is 'unconfounded' and the conditional independence assumption is not violated. Estimating the conditional probability of receiving the treatment given the pre-treatment variables allows us to match observations based on the propensity score. ${ }^{27}$ Then, once the propensity score to participate in treatment is estimated, the second step is to estimate the average effect of the treatment given the propensity score.

In this step one would ideally like to: (i) match cases and controls with exactly the same (estimated) propensity score; (ii) compute the effect of treatment for each value of

${ }^{27}$ Paul Rosenbaum and Donald B. Rubin, 'The Central Role of the Propensity Score in Observational Studies for Causal Effects', Biometrika, 70 (1983), 41-55. 
TA B LE 4 Binary Treatment Based on Time Out of Office (Frequencies and Percentages)

\begin{tabular}{|c|c|c|c|c|}
\hline & \multicolumn{2}{|c|}{$\begin{array}{l}\text { First specification } \\
\quad(>0 \text { vs } 0)\end{array}$} & \multicolumn{2}{|c|}{$\begin{array}{c}\text { Second specification } \\
\text { (Upper Decile vs The Rest) }\end{array}$} \\
\hline & Frequencies & Percentage & Frequencies & Percentage \\
\hline \multicolumn{5}{|c|}{ Time Out of Office (Y) } \\
\hline Non-treated & 542 & 67.16 & 697 & 86.37 \\
\hline Treated & 265 & 32.84 & 110 & 13.63 \\
\hline \multicolumn{5}{|c|}{ Time Out of Office $(F)$} \\
\hline Non-treated & 540 & 66.91 & 694 & 86.00 \\
\hline Treated & 267 & 33.09 & 113 & 14.00 \\
\hline
\end{tabular}

the (estimated) propensity score; and (iii) obtain the average of these conditional effects. Since in practice this is not feasible (it is rare to find pairs with exactly the same propensity score), there are several other alternatives available to perform this step. ${ }^{28}$ Here, I concentrate on two of them: radius and kernel matching on the score. Roughly put, the former consists of finding the control units (untreated) whose propensity scores differ from the score of the treated unit by less than a given tolerance level for all the control units; compare their outcomes (i.e. values of the main dependent variable) given the variables used in the estimation of the propensity score; and compute an average of the differences, which will be the average treatment effect for the treated. Alternatively, the kernel matching estimator can be interpreted as a particular version of the radius method in which every treated unit is matched with a weighted average of all control units with weights that are inversely proportional to the distance between the treated and control units.

In the particular case of this work, the procedure outlined above has taken the following form. To begin with, although I have been referring to treated and untreated (or control) units, the Time Out of Office treatment is not binary but continuous. Since the standard way to proceed with matching is through binary treatments, the first step has been to make the main independent variable dichotomous. ${ }^{29} \mathrm{I}$ have done this by following a twofold strategy. In the first specification, those parties not present in the previous government have been considered as having received the treatment. In other words, those with absolute Time Out of Office $(Y / F)>0$ are treated, while for the untreated controls Time Out of Office $(Y / F)=0$. The second specification defines the treatment group more restrictively. Those equal to or above the upper decile of the distribution of absolute Time Out of Office are the treated observations (Time Out of Office $(Y) \geq 5.33$ and Time Out of Office $(F) \geq 4$ ), while those below are the untreated control units. The frequencies for both treatment specifications are displayed in Table 4.

\footnotetext{
${ }^{28}$ See Sascha O. Becker and Andrea Ichino, 'Estimation of Average Treatment Effects Based on Propensity Scores', Stata Journal, 2 (2002), 358-77.

${ }^{29}$ There have been recent efforts to develop an extension of the propensity score methodology that allows estimating average causal effects with continuous treatments (see Keisuke Hirano and Guido W. Imbens, 'The Propensity Score with Continuous Treatments', in Andrew Gelman and Xiao-Li Meng, Applied Bayesian Modeling and Causal Inference from Incomplete-Data Perspectives, eds (Chichester, W. Sussex: Wiley, 2004)). However, it is a fairly new method that has rarely been applied. After considering this technique, in the end I decided that it was more reasonable to proceed in the standard way and 'binarize' the treatment.
} 
So, which characteristics make parties more inclined to participate in treatment? In other words, which variables should be included in the estimation of their propensity score? As suggested above, there are reasons to believe that some parties' characteristics make them more prone to longer periods out of office, such as their 'office-seekingness'. Although it is very difficult to observe this characteristic, some years ago Laver and Hunt provided a measure of such a feature based on country experts' judgements. ${ }^{30}$ The specific question put to experts was: 'forced to make a choice, would party leaders give up policy objectives in order to get into government, or would they sacrifice a place in government in order to maintain policy objectives?' The experts were asked to provide an evaluation on a scale ranging from 1 (give up place in government) to 20 (give up policy objectives). For each party, the authors report the raw means of country expert judgements and also a mean standard score calculated in relation to the scale and country in question. The latter is the pre-treatment variable used in the estimation of the propensity score.

It has to be acknowledged that these scores are overall assessments of parties' 'careers' without allowing for cross-time variation within each party. Additionally, the information is missing for some of the parties included in the previous analyses. These are certainly significant shortcomings, and so for robustness purposes I also estimated the propensity score using other variables. The results (not shown) were very similar. ${ }^{31}$

As Caliendo and Kopeinig point out, there is some controversy about which variables should be included in the estimation of the propensity score: 'there are both reasons for and against including all of the reasonable covariates available. Basically, ... the choice of variables should be based on ... theory and previous empirical findings' ${ }^{32}$ In order to make the estimation of the average treatment effect consistent with the analyses offered in the previous section, I have included all the independent variables used there (with the obvious exception of Time Out of Office). This follows Rubin and Thomas's advice against 'trimming' models in the name of parsimony, arguing that a variable should only be excluded from analysis if there is consensus that it is either completely unrelated to the outcome or not a proper covariate. If there are doubts on any of these two points, they explicitly advise the inclusion of all the relevant variables in the propensity score estimation. ${ }^{33}$

As said, the specific techniques chosen to match treated and untreated units have been radius and kernel matching. For the former, I have matched each treated variable with all controls within an interval of \pm 0.1 . As standard, the kernel used to weigh the importance of the control units given their propensity score distances to the treated observation has been the Gaussian or normal. To ensure rigorous comparability, the estimations have been produced with an option that imposes a common support by dropping treatment observations whose propensity score is higher than the maximum or minimum score of the control observations. ${ }^{34}$

${ }^{30}$ Michael Laver and William Ben Hunt. Policy and Party Competition (New York: Routledge, 1992).

${ }^{31}$ See Falcó-Gimeno, 'Portfolio Allocation and Time Out of Office in Coalition Governments'.

${ }^{32}$ Marco Caliendo and Sabine Kopeinig, 'Some Practical Guidance for the Implementation of Propensity Score Matching', Journal of Economic Surveys, 22 (2008), 31-72, pp. 38-9.

${ }^{33}$ Donald B. Rubin and Neal Thomas, 'Matching Using Estimated Propensity Scores: Relating Theory to Practice', Biometrics, 52 (1996), 249-64.

${ }^{34}$ The Stata module used to perform such analyses has been psmatch2 (see Edwin Leuven and Barbara Sianesi, 'Psmatch2: Stata Module to Perform Full Mahalanobis and Propensity Score Matching, Common Support Graphing, and Covariate Imbalance Testing', version 3.1.5 2may2009, computer software (Boston College Department of Economics, 2003), Statistical Software Components). As usual 
The coefficient estimates in Table 5 are negative as expected and the effects are statistically significant, regardless of the Time Out of Office specification and the type of matching technique used. In the light of these results, we are closer to being able to say that the time a given party has remained out of office causally affects the share of portfolios it obtains when bargaining over the formation of a coalition government. The matching procedure shows that, even when parties with similar ex ante propensities to being in opposition for a certain period of time are compared, actual absences in office hinder their prospects in the portfolio allocation process.

\section{CONCLUDING REMARKS}

Although the study of portfolio allocation in coalition governments has proved very fruitful for political scientists, academics have not assessed the role of parties' impatience to reach office more than anecdotally or in passing. This article has claimed that, despite the empirical strength of the relationship between parties' seats and portfolios, there are reasons to take other variables into consideration to improve our understanding of how coalition partners distribute ministerial posts. This work has argued that one of these variables might be how long parties have had to wait for the opportunity to leave the opposition benches and participate in a new government.

The key idea already has an intuitive appeal: the longer the period that parties have spent without enjoying the spoils of office, the more impatient they get, and thus the more they are willing to make concessions in the negotiation over government formation when they have the opportunity to enter office. This intuition has been supported substantively with some real-world examples and an informal argument has also been presented that assumes parties discount the future more the longer they have been in opposition. Two hypotheses have been put forward in this regard. On the one hand, the overall influence of long periods out of office when bargaining over portfolios should be negative. On the other hand, if we were to believe the predictions of bargaining models based on alternating offers, the fact of being the formateur should offset this disadvantage since formation offers are made based on receivers' impatience rather than on that of the proposer.

Empirical analyses have largely supported the theoretical expectations, using several different specifications of the dependent and independent variables. The last step of this research has been to explore further the issue of causality by providing additional evidence in favour of the negative effect of the length of time a given party has been in opposition on the office payoffs it manages to receive. This has been undertaken through matching 'treated' and 'untreated' parties based on similar propensities to be out of office.

In sum, this article has offered new insights into the study of portfolio allocation in coalition governments through the inclusion of a variable that has not previously been taken into account. This original contribution may be of use for future research, both on theoretical and empirical grounds. Among others, possible extensions should look further at the conditionality of the effect of time out of office. Most likely, distinct parties will be affected differently according to their characteristics beyond the (non-)formateur status. Ideology, for example, and its relation to the partisanship of previous governments, could be one possible characteristic to explore. Likewise, parties' internal organization may

(F'note continued)

when estimating average treatment effects for the treated with matching techniques, I have computed bootstrap standard errors with fifty iterations (as default in psmatch2). 
TABLE 5 Average Treatment Effect for the Treated with Two Matching Methods

\begin{tabular}{|c|c|c|c|c|c|c|c|c|}
\hline & \multicolumn{4}{|c|}{ Share of Portfolios (Non-weighted) } & \multicolumn{4}{|c|}{ Share of Portfolios (Weighted) } \\
\hline & Treated & Controls & $\begin{array}{l}\text { Difference } \\
\text { (obs. coeff.) }\end{array}$ & $\begin{array}{l}\text { Bootstrap } \\
\text { S.E. }\end{array}$ & Treated & Controls & $\begin{array}{l}\text { Difference } \\
\text { (obs. coeff.) }\end{array}$ & $\begin{array}{l}\text { Bootstrap } \\
\text { S.E. }\end{array}$ \\
\hline \multicolumn{9}{|c|}{ Treatment: Time Out of Office ( $>0$ vs 0 ) } \\
\hline \multicolumn{9}{|l|}{ Time Out of Office ( $Y$ ) } \\
\hline Unmatched & 0.3022 & 0.3864 & -0.0841 & & 0.2993 & 0.3906 & -0.0913 & \\
\hline Matched (Radius 0.1) & 0.3033 & 0.3148 & $-0.0115^{*}$ & 0.0064 & 0.3004 & 0.3119 & $-0.0115 * *$ & 0.0056 \\
\hline Matched (Gaussian Kernel) & & 0.3149 & $-0.0116^{*}$ & 0.0062 & & 0.3120 & $-0.0116^{* *}$ & 0.0056 \\
\hline \multicolumn{9}{|l|}{ Time Out of Office $(F)$} \\
\hline Unmatched & 0.3026 & 0.3864 & -0.0837 & & 0.2995 & 0.3907 & -0.0912 & \\
\hline Matched (Radius 0.1) & 0.3037 & 0.3135 & $-0.0098 *$ & 0.0059 & 0.3006 & 0.3108 & $-0.0102 *$ & 0.0059 \\
\hline Matched (Gaussian Kernel) & & 0.3135 & $-0.0098^{*}$ & 0.0059 & & 0.3108 & $-0.0102 *$ & 0.0052 \\
\hline \multicolumn{9}{|c|}{ Treatment: Time Out of Office (Upper Decile vs The Rest) } \\
\hline \multicolumn{9}{|c|}{ Time Out of Office ( $Y$ ) } \\
\hline Unmatched & 0.3127 & 0.3654 & -0.0527 & & 0.3082 & 0.3682 & -0.0601 & \\
\hline Matched (Radius 0.1) & 0.3163 & 0.3458 & $-0.0295 * *$ & 0.0130 & 0.3122 & 0.3466 & $-0.0344 * *$ & 0.0147 \\
\hline Matched (Gaussian Kernel) & & 0.3461 & $-0.0297 * *$ & 0.0118 & & 0.3471 & $-0.0349 * * *$ & 0.0130 \\
\hline \multicolumn{9}{|l|}{ Time Out of Office $(F)$} \\
\hline Unmatched & 0.3115 & 0.3658 & -0.0543 & & 0.3091 & 0.3684 & -0.0593 & \\
\hline Matched (Radius 0.1) & 0.3172 & 0.3504 & $-0.0332 * * *$ & 0.0118 & 0.3152 & 0.3522 & $-0.0369 * * *$ & 0.0143 \\
\hline Matched (Gaussian Kernel) & & 0.3524 & $-0.0352 * * *$ & 0.0133 & & 0.3542 & $-0.0389 * * *$ & 0.0141 \\
\hline
\end{tabular}

Notes: Logistic model to estimate the propensity score: $p$ (Time Out of Office (Bin.) $)=1 /(1+\exp (-\alpha-\beta($ Office-Seekingness $($ LH $))-$ $\beta$ (Seat Share) $-\beta($ Voting Weight $)-\beta($ Formateur $)))$. ${ }^{* * *} p<0.01, * * p<0.05, * p<0.10$. 
influence how far leaders look ahead when evaluating payoffs, as they may be rendered more or less vulnerable to the threat of replacement. Beyond party-specific features, institutions may also play a role. The extent to which they favour incumbents will probably affect parties' impatience, since in some countries those in opposition are already in a good position to influence policy. Another interesting and somewhat counterintuitive implication of the arguments presented in this work is that, everything else being equal, parties that have been out of government for long periods of time should be more likely to enter government as its relative price as a partner will decrease. Finally, and beyond office payoffs, the effect of this work's main independent variable on other types of concessions such as policy compromises would merit further attention as well. These are just some examples of how the contribution made here could be taken up in future research. 